\title{
The Effect of Three Different Bolus Doses of Propofol Using Total Intravenous Anaesthesia (TIVA) in Patients Undergoing Transvaginal Oocyte Retrieval with Regard to Total Propofol Consumption
}

\author{
Yuvaraj MK', Aiyappa DS ${ }^{2}$ \\ ${ }^{1}$ Assistant Professor, Department of Anesthesiology, Kodagu Institute of Medical Sciences, Madikere, Karnataka, ${ }^{2}$ Assistant Professor, Department of \\ Anesthesiology, Kodagu Institute of Medical Sciences, Madikere, Karnataka.
}

\section{Abstract}

Background: Total intravenous anaesthesia (TIVA) using propofol is one of the commonest techniques used for TVOR as a day care procedure by virtue of its adequate sedation and speedy clear headed recovery. Monitors like BIS or entropy help us to effectively titrate the drug so as to maintain optimal depth of anaesthesia and minimise drug consumption. Subjects and Methods: After obtaining Institutional Review Board approval, this prospective randomised controlled study was conducted in the Department of Anaesthesiology and Intensive care, Medical College Hospital. All ASA Grade I and II female patients of reproductive age group coming for oocyte retrieval under general anaesthesia who can understand the informed consent form were included in the study. Results: There is a statistically significant difference observed between group P1 and P3 with regard to Proportion of patients not requiring rescue boluses. No significant difference was observed between P1 - P2 and P2-P3 groups. There was a statistically significant difference observed between groups P1 and P3 in respect to total propofol consumption. No significant difference observed between P1-P2 and P2-P3. Conclusion: Bolus dose of propofol can be an induction dose of choice in oocyte retrieval patients as it requires less rescue boluses compared to $1.0 \mathrm{mg} / \mathrm{kg}$ and and overall propofol consumption was less than $2 \mathrm{mg} / \mathrm{kg}$ but more than $1 \mathrm{mg} / \mathrm{kg}$.

Keywords: Propofol, Total Intravenous Anaesthesia, Transvaginal Oocyte Retrieval.

Corresponding Author: Dr. Aiyappa DS, Assistant Professor, Department of Anesthesiology, Kodagu Institute of Medical Sciences, Madikere, Karnataka.

Received: February 2019

Accepted: February 2019

\section{Introduction}

The first successful live birth following In Vitro Fertilisation (IVF) of a human oocyte was performed in 1978 by Steptoe and Edwards. Assisted reproduction technology (ART) is a complex procedure consisting of various steps starting from stimulation of ovaries to oocyte pick up, sperm processing and the intricate embryology laboratory details for embryo formation and finally its implantation into the uterus. Recovery of oocytes from the ovary is the fundamental step of IVF treatment. Although less invasive than the previously practised laparoscopic approach, Transvaginal Oocyte Retrieval (TVOR) is the only painful procedure performed during the entire ART treatment. Pain during oocyte retrieval is caused by puncture of vaginal skin and ovarian capsule by the aspirating needle as well as manipulation within the ovary during the entire procedure. ${ }^{[1]}$

Types of pain relief used for TVOR includes conscious sedation, local anaesthesia, epidural, spinal anaesthesia and general anaesthesia. However, none of the techniques proved superior over other. It is prudent for anaesthesia providers to be aware of the potential effects that anaesthetic agents may have on gametes and embryos. ${ }^{[2]}$

Total intravenous anaesthesia (TIVA) using propofol is one of the commonest techniques used for TVOR as a day care procedure by virtue of its adequate sedation and speedy clear headed recovery. Monitors like BIS or entropy help us to effectively titrate the drug so as to maintain optimal depth of anaesthesia and minimise drug consumption. ${ }^{[3]}$ Recent studies suggest that there is a time and dose dependent undesirable effect of propofol on fertilisation of oocyte .Thus it is necessary for us to design a safe protocol for anaesthesia in oocyte retrieval that minimises drug administration and thereby unwanted effects. ${ }^{[4]}$ Keeping this in mind our study aims at evaluating the optimal bolus dose of propofol that can provide safe and effective anaesthesia facilitating optimum surgical conditions and speedy post operative recovery.

\section{Subjects and Methods}

After obtaining Institutional Review Board approval, this prospective randomised controlled study was conducted in 
the Department of Anaesthesiology and Intensive care, Medical College Hospital.

\section{Study Design}

The study was a prospective, single blinded, randomised controlled study.

\section{Study Population}

Female patients of reproductive age group coming for oocyte retrieval under general anaesthesia at IVF centre, Maulana Azad Medical College.

\section{Inclusion Criteria}

All ASA Grade I and II female patients of reproductive age group coming for oocyte retrieval under general anaesthesia who can understand the informed consent form were included in the study.

\section{Exclusion criteria}

1. Obese Patients with $\mathrm{BMI} \geq 30$

2. Patients with limited mandibular protrusion, edentulous and with history of snoring.

3. Patients with history suggestive of gastro esophageal reflux disorders

4. History suggestive of hypersensitivity to propofol

5. Surgical procedure time $\geq 30$ minutes.

6. History of alcohol intake, smoking or on any unprescribed drugs.

7. Patients with facial nerve palsy.

8. History of patients on anticonvulsants or any other centrally acting medication

\section{Allocation of groups}

75 patients were randomly allocated into 3 study groups of 25 patients by a computer generated randomisation table:

Group P1: propofol $2 \mathrm{mg} / \mathrm{kg}$

Group P2: propofol $1.5 \mathrm{mg} / \mathrm{kg}$

Group P3: propofol $1 \mathrm{mg} / \mathrm{kg}$

\section{PAC}

Detailed pre anaesthetic check up was done a day prior to surgery and appropriate investigations were carried out. The anaesthetic technique and the questionnaire were explained to the patients and an informed written consent was taken from all the patients.

Patients were kept fasting overnight prior to surgery and were premedicated with Tab. Ranitidine $150 \mathrm{mg}$ and Tab. Alprazolam $0.25 \mathrm{mg}$ on the night before surgery and repeated on the next day one hour prior to surgery with sip of water.

In operation theatre: Standard pre use checks of anaesthesia workstation and ancillary equipment were performed. After shifting the Patient to OT, Routine monitors like heart rate (HR), blood pressure (BP), and SPO2 (saturation of oxygen)were attached. Commercially available disposable entropy sensor strip was applied after skin preparation as recommended by the manufacturer. Entropy module of the S/5 Anaesthesia monitor (GE Healthcare, Finland: formerly Datex-Ohmeda, Helsinki, Finland) was used.

\section{Results}

Table 1: Proportion Of Patients Who Did Not Require Rescue

Boluses

\begin{tabular}{|l|l|}
\hline Group & $\begin{array}{l}\text { Proportion of patients who did not } \\
\text { require rescue boluses }\end{array}$ \\
\hline $\mathrm{P} 1(2 \mathrm{mg} / \mathrm{kg})$ & $88 \%$ \\
\hline $\mathrm{P} 2(1.5 \mathrm{mg} / \mathrm{kg})$ & $72 \%$ \\
\hline $\mathrm{P} 3(1 \mathrm{mg} / \mathrm{kg})$ & $56 \%$ \\
\hline $\mathrm{P}$ value & 0.042 \\
\hline
\end{tabular}

$88 \%$ in group P1 $(2 \mathrm{mg} / \mathrm{kg}), 72 \%$ in group $\mathrm{P} 2(1.5 \mathrm{mg} / \mathrm{kg})$ and $56 \%$ in group $\mathrm{P} 3(1 \mathrm{mg} / \mathrm{kg})$ patients did not require boluses. There is a statistically significant difference observed between the three groups with regard to proportion of patients not requiring boluses. Out of 25 patients in group P1 $(2 \mathrm{mg} / \mathrm{kg}) 3$ patients required boluses. In group P2 (1.5 $\mathrm{mg} / \mathrm{kg}) 7$ patients required boluses. In group P3 $(1 \mathrm{mg} / \mathrm{kg}) 11$ patients required boluses.

Table 1A: Comparison between P1 and P2

\begin{tabular}{|l|l|}
\hline Group & $\begin{array}{l}\text { Proportion of patients who do not require rescue } \\
\text { boluses }\end{array}$ \\
\hline $\mathrm{P} 1(2 \mathrm{mg} / \mathrm{kg})$ & 88 \\
\hline $\mathrm{P} 2(1.5 \mathrm{mg} / \mathrm{kg})$ & 72 \\
\hline $\mathrm{P}$ value & 0.157 \\
\hline
\end{tabular}

Table 1B: Comparison between $P 2$ and $P 3$

\begin{tabular}{|l|l|}
\hline Group & $\begin{array}{l}\text { Proportion of patients who do not require rescue } \\
\text { boluses }\end{array}$ \\
\hline $\mathrm{P} 2(1.5 \mathrm{mg} / \mathrm{kg})$ & 72 \\
\hline $\mathrm{P} 3(1 \mathrm{mg} / \mathrm{kg})$ & $56 \%$ \\
\hline $\mathrm{P}$ value & 0.170 \\
\hline
\end{tabular}

Table 1C: Comparison between P1 and P3

\begin{tabular}{|l|l|}
\hline Group & $\begin{array}{l}\text { Proportion of patients who do not require rescue } \\
\text { boluses }\end{array}$ \\
\hline $\mathrm{P} 1(2 \mathrm{mg} / \mathrm{kg})$ & $88 \%$ \\
\hline $\mathrm{P} 3(1 \mathrm{mg} / \mathrm{kg})$ & $56 \%$ \\
\hline $\mathrm{P}$ value & 0.012 \\
\hline
\end{tabular}

There is a statistically significant difference observed between group P1 and P3 with regard to Proportion of patients not requiring rescue boluses. No significant difference was observed between P1 - P2 and P2-P3 groups. In group $\mathrm{P} 1,3$ patients required one rescue bolus.

In group P2, 4 patients were given one rescue bolus and 2 patients required 2 bolus

In group P3, 6 patients were given one rescue bolus, 3 patients required 2 boluses, another 3 patients required 3 boluses and 1 patient required 4 boluses

\begin{tabular}{|l|l|l|l|l|l|}
\hline Table 2: Rescue Bolus At Regular Interval \\
& Induction & $\begin{array}{l}\mathbf{0} \text { T0 5 } \\
\text { mins }\end{array}$ & $\begin{array}{l}\mathbf{5} \text { TO } \\
\mathbf{1 0} \\
\text { MINS }\end{array}$ & $\begin{array}{l}\mathbf{1 0} \\
\mathbf{1 5} \\
\text { MINS }\end{array}$ & $\begin{array}{l}\mathbf{1 5} \text { TO } \\
\text { MINS }\end{array}$ \\
\hline $\mathrm{P} 1(2 \mathrm{mg} / \mathrm{kg})$ & $0 \%$ & $4.0 \%$ & $8 \%$ & $.0 \%$ & $.0 \%$ \\
\hline $\mathrm{P} 2(1.5 \mathrm{mg} / \mathrm{kg})$ & $0 \%$ & $8.0 \%$ & $12.0 \%$ & $.15 .82 \%$ & $14.3 \%$ \\
\hline $\mathrm{P} 3(1 \mathrm{mg} / \mathrm{kg})$ & $0 \%$ & $24.0 \%$ & $25.0 \%$ & $14.3 \%$ & $23.0 \%$ \\
\hline $\mathrm{P}$ value & & 0.031 & 0.098 & 0.147 & 0.147 \\
\hline
\end{tabular}

Table 2A: Comparison between P1 and P2

\begin{tabular}{|l|l|l|l|l|l|} 
& Induction & $\begin{array}{l}\text { 0 T0 5 } \\
\text { mins }\end{array}$ & $\begin{array}{l}\mathbf{5} \text { TO } \\
\mathbf{1 0} \\
\text { MINS }\end{array}$ & $\begin{array}{l}\mathbf{1 0} \text { TO } \\
\mathbf{1 5} \\
\text { MINS }\end{array}$ & $\begin{array}{l}\mathbf{1 5} \text { TO } \\
\mathbf{2 0} \\
\text { MINS }\end{array}$ \\
\hline $\mathrm{P} 1(2 \mathrm{mg} / \mathrm{kg})$ & $0 \%$ & $4.0 \%$ & $8 \%$ & $.0 \%$ & $.0 \%$ \\
\hline $\mathrm{P} 2(1.5 \mathrm{mg} / \mathrm{kg})$ & $0 \%$ & $8.0 \%$ & $12.0 \%$ & $.15 .82 \%$ & $14.3 \%$ \\
\hline $\mathrm{P}$ value & & 0.5 & 0.5 & 0.115 & 0.5 \\
\hline
\end{tabular}


Table 2B: Comparison between $\mathrm{P3}$ and $\mathrm{P2}$

\begin{tabular}{|l|l|l|l|l|l|}
\hline & Induction & $\begin{array}{l}\mathbf{0} \text { T0 5 } \\
\text { mins }\end{array}$ & $\begin{array}{l}\mathbf{5} \text { TO } \\
\mathbf{1 0} \\
\text { MINS }\end{array}$ & $\begin{array}{l}\mathbf{1 0} \text { TO } \\
\mathbf{1 5} \\
\text { MINS }\end{array}$ & $\begin{array}{l}\mathbf{1 5} \text { TO } \\
\text { MINS }\end{array}$ \\
\hline $\mathrm{P} 3(1 \mathrm{mg} / \mathrm{kg})$ & $0 \%$ & $24.0 \%$ & $25.0 \%$ & $14.3 \%$ & $23.0 \%$ \\
\hline $\mathrm{P} 2(1.5 \mathrm{mg} / \mathrm{kg})$ & $0 \%$ & $8.0 \%$ & $12.0 \%$ & $.15 .82 \%$ & $14.3 \%$ \\
\hline $\mathrm{P}$ value & & 0.123 & 0.211 & 0.619 & 0.561 \\
\hline
\end{tabular}

Table 2C: Comparison between $P 3$ and $P 1$

\begin{tabular}{|l|l|l|l|l|l|}
\hline & Induction & $\begin{array}{l}\mathbf{0} \text { T0 5 } \\
\text { mins }\end{array}$ & $\begin{array}{l}\text { 5 TO 10 } \\
\text { MINS }\end{array}$ & $\begin{array}{l}\mathbf{1 0} \text { TO } \\
\mathbf{1 5} \\
\text { MINS }\end{array}$ & $\begin{array}{l}\mathbf{1 5} \text { TO } \\
\mathbf{2 0} \\
\text { MINS }\end{array}$ \\
\hline $\mathrm{P} 3(1 \mathrm{mg} / \mathrm{kg})$ & $0 \%$ & $24.0 \%$ & $25.0 \%$ & $14.3 \%$ & $23.0 \%$ \\
\hline $\mathrm{P} 1(2 \mathrm{mg} / \mathrm{kg})$ & $0 \%$ & $4.0 \%$ & $8 \%$ & $.0 \%$ & $.0 \%$ \\
\hline $\mathrm{P}$ value & & 0.049 & 0.110 & 0.135 & 0.251 \\
\hline
\end{tabular}

There is statistically significant difference observed between group P1 and P3 with regard to rescue bolus at $0-5$ minutes, though not in the rest of the time interval for the above groups. No significant difference was observed between P1P2 and P2-P3 with regard to rescue bolus at any interval. In group P1, 4 patients infusion rate were decreased because of low entropy values (State entropy $\leq 40$ ). 2 patients infusion rate were decreased in both $\mathrm{P} 2$ and $\mathrm{P} 3$ group.

Table 3: Pulse Rate
\begin{tabular}{|l|l|l|l|l|l|l|l|l|}
\hline Group & $\begin{array}{l}\text { basel } \\
\text { ine }\end{array}$ & $\begin{array}{l}\text { induc } \\
\text { tion }\end{array}$ & $\begin{array}{l}\mathbf{5 m} \\
\text { in }\end{array}$ & $\begin{array}{l}\mathbf{1 0} \\
\text { min }\end{array}$ & $\begin{array}{l}\mathbf{1 5} \\
\text { min }\end{array}$ & $\begin{array}{l}\mathbf{2 0} \\
\text { min }\end{array}$ & $\begin{array}{l}\mathbf{2 5} \\
\text { min }\end{array}$ & $\begin{array}{l}\mathbf{3 0} \\
\text { min }\end{array}$ \\
\hline P1(2mg/ & 91.24 & 76.60 & 72. & 70.9 & 73.2 & 64.4 & 63.2 & 60.5 \\
$\mathrm{~kg})$ & & & 68 & 6 & 6 & 3 & 5 & 0 \\
\hline P2(1.5m & 90.32 & 74.92 & 71. & 72.7 & 72.5 & 76.8 & 79.0 & 97.0 \\
g/kg) & & & 76 & 6 & 6 & 8 & 0 & 0 \\
\hline P3(1mg/ & 94.36 & 79.48 & 75. & 75.2 & 79.1 & 82.3 & 76.0 & 84.0 \\
kg) & & & 96 & 1 & 9 & 8 & 0 & 0 \\
\hline P value & 0.619 & 0.311 & 0.2 & 0.27 & 0.04 & 0.00 & 0.10 & 0.15 \\
& & & 71 & 4 & 3 & 0 & 2 & 6 \\
\hline
\end{tabular}

The pulse rate gradually decreased in all the three groups after induction. There was a significant difference observed in fall of pulse rate at 15 and 20 minutes. However no significant difference observed between the groups at any other interval.

Also statistical significant difference in fall of pulse rate was observed between group P1 and P3 at 15th $(\mathrm{p}=0.035)$ and 20th minute $(\mathrm{p}=0.00)$. Between group $\mathrm{P} 1$ and $\mathrm{P} 2$ statistical difference was observed at 15 th minute $(p=0.035)$ Between group P2 and P3 a statistical difference was observed at 20th minute $(\mathrm{p}=0.011)$.

Table 4: Mean Arterial Pressure

\begin{tabular}{|l|l|l|l|l|l|l|l|l|}
\hline Group & $\begin{array}{l}\text { base } \\
\text { line }\end{array}$ & $\begin{array}{l}\text { induc } \\
\text { tion }\end{array}$ & $\begin{array}{l}\mathbf{0} \\
\text { to } \\
\mathbf{5} \\
\mathbf{m i} \\
\mathbf{n}\end{array}$ & $\begin{array}{l}\mathbf{5} \text { to } \\
\mathbf{1 0} \\
\mathbf{m i} \\
\mathbf{n}\end{array}$ & $\begin{array}{l}\mathbf{1 0} \\
\text { to15 } \\
\text { min }\end{array}$ & $\begin{array}{l}\mathbf{1 5} \\
\text { to20 } \\
\text { min }\end{array}$ & $\begin{array}{l}\mathbf{2 0} \\
\text { to25 } \\
\text { min }\end{array}$ & $\begin{array}{l}\mathbf{2 5} \\
\text { to30 } \\
\text { min }\end{array}$ \\
\hline $\mathrm{P} 1(2 \mathrm{mg}$ & 93.6 & 72.16 & 71. & 77. & 79.4 & 73.8 & 78.5 & 78.0 \\
$/ \mathrm{kg})$ & 0 & & 04 & 80 & 2 & 6 & 0 & 0 \\
\hline $\mathrm{P} 2(1.5$ & 92.2 & 75.76 & 75. & 80. & 85.8 & 89.1 & 90.6 & 101. \\
$\mathrm{mg} / \mathrm{kg})$ & 0 & & 64 & 84 & 9 & 2 & 0 & 00 \\
\hline $\mathrm{P} 3(1 \mathrm{mg}$ & 93.2 & 76.92 & 76. & 80. & 83.1 & 84.4 & 90.0 & 83.0 \\
/kg) & 8 & & 16 & 67 & 0 & 6 & 0 & 0 \\
\hline $\mathrm{P}$ value & 0.79 & 0.167 & 0.0 & 0.4 & 0. & 0.01 & 0.10 & 0.35 \\
& 1 & & 35 & 31 & 160 & 1 & 6 & 0 \\
\hline
\end{tabular}

The mean arterial pressure gradually decreased in all the three groups after induction. There was a significant difference observed in fall of mean arterial pressure at 5 minute and 20 minute. However, no significant difference was observed between the groups at any other interval.

Also statistical significant difference in fall of mean arterial pressure was observed between group $\mathrm{P} 1$ and $\mathrm{P} 3$ at 5 th $(\mathrm{p}=0.037)$ and 20th minute $(\mathrm{p}=0.036)$. Between group $\mathrm{P} 1$ and P2 no statistical difference was observed. Between group P2 and P3 a statistical difference was observed at 5th $(\mathrm{p}=0.01)$ and 20th minute $(\mathrm{p}=0.002)$.

Table 5: Total Propofol Consumption (TP)

\begin{tabular}{|l|lll|}
\hline Group & $\begin{array}{l}\text { Total Propofol Consumption (TP in mg) } \\
(\mathbf{m e a n} \pm \text { SD) }\end{array}$ & & \\
\hline $\mathrm{P} 1(2 \mathrm{mg} / \mathrm{kg})$ & $260.69 \pm 58.526$ & & \\
\hline $\mathrm{P} 2(1.5 \mathrm{mg} / \mathrm{kg})$ & $259.14 \pm 79.334$ & & \\
\hline $\mathrm{P} 3(1 \mathrm{mg} / \mathrm{kg})$ & $216.57 \pm 71.947$ & & \\
\hline $\mathrm{p}$ value & 0.049 & & \\
\hline
\end{tabular}

The Total propofol consumption was found to be $260.69 \mathrm{mg}$ in group P1 $(2 \mathrm{mg} / \mathrm{kg}), 259.14 \mathrm{mg}$ in group P2 $(1.5 \mathrm{mg} / \mathrm{kg})$ and $216.57 \mathrm{mg}$ in group P3 $(1 \mathrm{mg} / \mathrm{kg})$. This difference was found to be statistically significant

Table 5A: Comparison between P1 and P2
\begin{tabular}{|l|lll|}
\hline Group & $\begin{array}{l}\text { Total Propofol Consumption } \\
(\mathbf{m e a n} \pm \text { SD) }\end{array}$ \\
\hline $\mathrm{P} 1(2 \mathrm{mg} / \mathrm{kg})$ & $260.69 \pm 58.526$ \\
\hline $\mathrm{P} 2(1.5 \mathrm{mg} / \mathrm{kg})$ & $259.14 \pm 79.334$ \\
\hline $\mathrm{p}$ value & 0.205 \\
\hline
\end{tabular}

TABLE 5B: Comparison between $P 2$ and $P 3$

\begin{tabular}{|c|c|}
\hline Group & 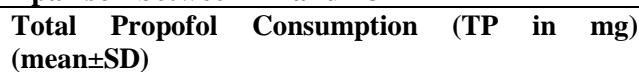 \\
\hline $\mathrm{P} 2(1.5 \mathrm{mg} / \mathrm{kg})$ & $259.14 \pm 79.334$ \\
\hline $\mathrm{P} 3(1 \mathrm{mg} / \mathrm{kg})$ & $216.57 \pm 71.947$ \\
\hline $\mathrm{p}$ value & 0.053 \\
\hline
\end{tabular}

TABLE 5C: Comparison between P1 and P3

\begin{tabular}{|l|l|}
\hline Group & Total Propofol Consumption $($ TP in mg) $($ mean \pm SD) \\
\hline $\mathrm{P} 1(2 \mathrm{mg} / \mathrm{kg})$ & $260.69 \pm 58.526$ \\
\hline $\mathrm{P} 3(1 \mathrm{mg} / \mathrm{kg})$ & $216.57 \pm 71.947$ \\
\hline $\mathrm{p}$ value & 0.021 \\
\hline
\end{tabular}

There was a statistically significant difference observed between groups $\mathrm{P} 1$ and $\mathrm{P} 3$ in respect to total propofol consumption. No significant difference observed between $\mathrm{P} 1-\mathrm{P} 2$ and $\mathrm{P} 2-\mathrm{P} 3$.

\section{TABLE 6: Total Fentanyl ConsumptioN (TF)}

TABLE 6: Total Fentanyl ConsumptioN (TF)
\begin{tabular}{|l|l|}
\hline Group & Total fentanyl Consumption $($ mcg) $($ mean \pm SD) \\
\hline $\mathrm{P} 1(2 \mathrm{mg} / \mathrm{kg})$ & $114.80 \pm 13.577$ \\
\hline $\mathrm{P} 2(1.5 \mathrm{mg} / \mathrm{kg})$ & $120.40 \pm 20.306$ \\
\hline $\mathrm{P} 3(1 \mathrm{mg} / \mathrm{kg})$ & $115.36 \pm 16.018$ \\
\hline $\mathrm{p}$ value & 0.438 \\
\hline
\end{tabular}

The Total fentanyl consumption was found to be $114.80 \mathrm{mcg}$ in group P1 $(2 \mathrm{mg} / \mathrm{kg}), 120.40 \mathrm{mcg}$ in group P2 $(1.5 \mathrm{mg} / \mathrm{kg})$ and $115.36 \mathrm{mcg}$ in group P3 $(1 \mathrm{mg} / \mathrm{kg})$. There was no statistically significant difference was observed.

\section{Discussion}

In our study we have used the technique of Total Intravenous Anaesthesia using Midazolam, Fentanyl, and propofol in all patients. We kept the patient under spontaneous respiration using bag and mask ventilation. We also monitored the depth of anaesthesia using entropy.

All the three groups were similar in their demographic 
profiles, i.e. age, sex, weight distribution and ASA physical status. The duration of Surgery was comparable between the three groups $(\mathrm{p}=0.692)$.

$88 \%$ patients in group $\mathrm{P} 1(2 \mathrm{mg} / \mathrm{kg}), 72 \%$ in group $\mathrm{P} 2$ $(1.5 \mathrm{mg} / \mathrm{kg})$ and $56 \%$ in group P3 $(1 \mathrm{mg} / \mathrm{kg})$ did not require boluses. There was statistically significant difference observed between group $\mathrm{P} 1$ and $\mathrm{P} 3$ with respect to proportion of patients not requiring rescue boluses. Although we observed a difference between groups P1 with P2 and P2, with P3, it was not statistically significant. Thus adequate level of anaesthetic depth required for oocyte retrieval patients was not achieved with an induction dose of $1 \mathrm{mg} / \mathrm{kg}$ (P3) and was achieved with an induction dose of $1.5 \mathrm{mg} / \mathrm{kg}$ (P2) and $2 \mathrm{mg} / \mathrm{kg}$ (P1). The following studies compared $1.5 \mathrm{mg} / \mathrm{kg}$ with $2 \mathrm{mg} / \mathrm{kg}$ and they found concordant result with regard to anaesthetic depth.

In 2013, M Zitta et al did a study on deleterious effect of propofol on invitro fertilisation and compared $1.5 \mathrm{mg} / \mathrm{kg}$ with $2 \mathrm{mg} / \mathrm{kg}$ induction dose of propofol. They found no difference in anaesthetic depth, age, no of oocytes retrieved, fertilisation rate and embryo quality between the 2 groups but the pregnancy rate was higher in $1.5 \mathrm{mg} / \mathrm{kg}$ group. Finally they concluded that administration high dose of propofol produces a negative late effect on human embryo development. ${ }^{[5]}$

In 1985 Rolly, G. and Versichelen, L compared $1.5 \mathrm{mg} / \mathrm{kg}$ of propofol induction dose with $2 \mathrm{mg} / \mathrm{kg}$ propofol induction dose and $4 \mathrm{mg} / \mathrm{kg}$ of thiopentone in Thirty premedicated ASA I or II patients scheduled for minor gynaecological surgery. They observed that $1.5 \mathrm{mg} / \mathrm{kg}$ group has lesser apnoec time, better hemodynamic stability, and with same anaesthetic depth when compared with $2 \mathrm{mg} / \mathrm{kg}$ group. ${ }^{[6]}$

In 2004 Ercan et al did a study titled "Assessing propofol induction of anaesthesia dose using bispectral index analysis" and they compared $2 \mathrm{mg} / \mathrm{kg}$ bolus dose of propofol with BIS guided propofol bolus dose. They found that propofol bolus for induction using BIS decreased the total propofol dose by $36-43 \%$ and hence propofol consumption. The hemodynamic stability is more in less propofol dose group than with the $2 \mathrm{mg} / \mathrm{kg}$ group. ${ }^{[7]}$

Thus in oocyte retrieval patients exposure to higher dose of propofol might affect the outcome of IVF patients. Hence, 2 $\mathrm{mg} / \mathrm{kg}$ of induction dose is not a good choice in this subset of patients since $1.5 \mathrm{mg} / \mathrm{kg}$ can achieve the same anaesthetic depth as that of $2 \mathrm{mg} / \mathrm{kg}$.

However, no studies were available in literature with respect to comparison of $1 \mathrm{mg} / \mathrm{kg}$ and $1.5 \mathrm{mg} / \mathrm{kg}$ induction dose of propofol. In our study, $1 \mathrm{mg} / \mathrm{kg}$ patients (around $50 \%$ ) did not maintain required anaesthetic depth without rescue boluses. Hence $1.5 \mathrm{mg} / \mathrm{kg}$ is the better dose for oocyte retrieval patients when compared to $1 \mathrm{mg} / \mathrm{kg}$ and $2 \mathrm{mg} / \mathrm{kg}$.

Comparing group P1 with P2 and P2 with P3 no statistical significant difference was observed with regard to rescue bolus at any interval during the study. Whereas comparing group P1 with P3, statistically significant difference was observed at $0-5$ minutes. $4 \%$ of patients in group P1 $(2 \mathrm{mg} / \mathrm{kg}), 8 \%$ in group P2 $(1.5 \mathrm{mg} / \mathrm{kg})$, and $24 \%$ in group P3 $(1 \mathrm{mg} / \mathrm{kg})$ were required rescue bolus at $0-5$ minutes.

It again indicates that $1 \mathrm{mg} / \mathrm{kg}$ (P3) is not a sufficient dose for mask ventilation and surgical stimulation in oocyte retrieval patients.
In our study $1 \mathrm{mg} / \mathrm{kg}$ group required more rescue boluses and it was statistically significant indicating that adequate depth was not maintained in this group. Hence it is not a good choice for oocyte retrieval patients.

An inadequate depth of anaesthesia necessitates more rescue boluses and maintaining adequate depth of anaesthesia is very important in oocyte retrieval patients since any movement of the patient increases the chances of needle injury to adjacent pelvic organ and structures.

In 2004, a review of complications following transvaginal oocyte retrieval for in-vitro fertilization by Salem A ElShawarby, et al observed that the most common complications of TVOR are haemorrhage, trauma and injury of pelvic structures. This may be due to the aspiration needle injuring the adjacent pelvic organs and structures. ${ }^{[8]}$

The Total propofol consumption was found to be $260.69 \pm$ $58.526 \mathrm{mg}$ in group P1 $(2 \mathrm{mg} / \mathrm{kg}), 259.14 \pm 79.334 \mathrm{mg}$ in group P2 $(1.5 \mathrm{mg} / \mathrm{kg})$ and $216.57 \pm 71.947 \mathrm{mg}$ in group P3 $(1 \mathrm{mg} / \mathrm{kg})$. This difference was found to be statistically significant. There was a statistically significant difference observed between groups P1 and P3 in respect to total propofol consumption. No significant difference was observed comparing groups P1 with P2 and P2 with P3.

In 1999 Frank Christiaens et al did a study on propofol concentrations in follicular fluid during general anaesthesia in TVOR and observed that mean follicular fluid concentration increased linearly with time and cumulative dose administered. They concluded that propofol based anaesthetic technique resulted in significant concentration of this agent in follicular fluid, which is related to the dose administered and to the duration of exposure. ${ }^{[9]}$

However, in 2000 a study by Ben Shlomo et al on the effect of propofol anaesthesia on oocyte fertilisation and embryo quality showed that duration of exposure does not affect oocyte quality. ${ }^{[10]}$

Even though there is a conflicting result among the studies, the embryo quality depends at least on the dose administered and hence total propofol consumption.

In this study the total propofol consumption is more with 2 $\mathrm{mg} / \mathrm{kg}$ group which may affect the outcome of ovum pick up patients. Although clinically less propofol consumption was seen with $1 \mathrm{mg} / \mathrm{kg}$, but to maintain adequate depth, more number of rescue boluses was needed. However total propofol consumption with $1 \mathrm{mg} / \mathrm{kg}$ and $1.5 \mathrm{mg} / \mathrm{kg}$ groups was not statistically significant. Hence $1.5 \mathrm{mg} / \mathrm{kg}$ is the better choice in oocyte retrieval patients.

The pulse rate gradually decreased with respect to time in all the three groups after induction. There was a significant difference observed between three groups in fall of pulse rate at 15 to 20 minutes. However no significant difference observed between the groups at any other interval.

Also statistical significant difference in fall of pulse rate was observed between group P1 and P3 at 15 th $(\mathrm{p}=0.035)$ and 20th minute $(\mathrm{p}=0.00)$. Between group $\mathrm{P} 1$ and $\mathrm{P} 2$ statistical difference was observed at 15 th minute $(p=0.035)$. Between the groups P1 and P2 a statistical difference was observed at 20th minute $(\mathrm{p}=0.011)$.

The mean arterial pressure gradually decreased in all the three groups after induction. There was a significant difference observed between three groups in fall of mean arterial pressure at 5 minute and 20 minute. However no 
significant difference observed between the three groups at any other interval. Also statistical significant difference in fall of mean arterial pressure was observed between group P1 and $P 3$ at 5 th $(p=0.037)$ and 20th minute $(p=0.036)$. Between group P1 and P2 no statistical difference was observed. Between group $\mathrm{P} 1$ and $\mathrm{P} 2$ a statistical difference was observed at 5th $(\mathrm{p}=0.01)$ and 20th minute $(\mathrm{p}=0.002)$.

Thus the fall in mean arterial pressure at 5 minutes was due to induction dose and its degree of fall directly varied with the dosage.

This is concordant with results obtained by Thomas et al in 1992 in a study titled 'sympathetic response to induction of anaesthesia in humans with propofol or etomidate' and they observed fall in pulse rate and BP with propofol. They concluded that both cardiac and baroslopes were significantly reduced with propofol which is mediated by an inhibition of the sympathetic nervous and impairment of baroreflex regulatory mechanism. ${ }^{[1]}$

Another study in 2011 by Nitin k shah et al titled effect of propofol titration v/s bolus induction on hemodynamics and bispectral index compared fixed bolus dose with titrated bolus dose of propofol and they observed a significant fall of $\mathrm{BP}$ and heart rate observed with fixed dose of $2 \mathrm{mg} / \mathrm{kg}{ }^{[12]}$ They also observed a lesser degree of fall in BP with titration of dose.

Another study in 2011 by Sennur Uzun et al compared three different injection speeds of propofol on blood pressure, dose and time of induction and they observed degree of fall in BP decreased as the speed of injection. ${ }^{[13]}$ However, in our study we did not record the speed of propofol injection.

The fall in pulse rate and mean arterial pressure at 15 th and 20th was due to the continuous infusion of propofol.

The Total fentanyl consumption was found to be $114.80 \mu \mathrm{g}$ in group P1 $(2 \mathrm{mg} / \mathrm{kg}), 120.40 \mu \mathrm{g}$ in group P2 $(1.5 \mathrm{mg} / \mathrm{kg})$ and $115.36 \mu \mathrm{g}$ in group P3 $(1 \mathrm{mg} / \mathrm{kg})$. No statistically significant difference was observed among the three groups. None of the patient in the entire three groups showed RE-SE gap > 10 at different intervals which indicates $2 \mu \mathrm{g} / \mathrm{kg}$ of fentanyl is an optimal analgesic dose in oocyte retrieval. Entropy unlike other monitors for depth of anaesthesia helps us to differentiate between the hypnotic and analgesic components of General Anaesthesia. It displays two indices- State Entropy (SE) and Response Entropy (RE). These indices individually reflect the hypnotic component and a value of 40-60 are considered appropriate for GA. The RE-SE gap, on the other hand, tells us about the analgesic component and a difference of more than 10 indicates need for supplementing analgesia to the patients. ${ }^{[14]}$

\section{Conclusion}

We thus conclude that $1.5 \mathrm{mg} / \mathrm{kg}$ bolus dose of propofol can be an induction dose of choice in oocyte retrieval patients, since:

- It required less rescue boluses compared to $1.0 \mathrm{mg} / \mathrm{kg}$ and almost comparable to that of $2 \mathrm{mg} / \mathrm{kg}$.

- Overall propofol consumption was less than $2 \mathrm{mg} / \mathrm{kg}$ but more than $1 \mathrm{mg} / \mathrm{kg}$; however statistically not significant.

- Hemodynamic parameters were more stable compared to $2 \mathrm{mg} / \mathrm{kg}$ and almost comparable to $1 \mathrm{mg} / \mathrm{kg}$.

- Recovery profile was faster than $2 \mathrm{mg} / \mathrm{kg}$ but delayed compared to $1 \mathrm{mg} / \mathrm{kg}$.

\section{References}

1. Virgil S. Manica, Angela M. Bader, Regina Fragneto, , Lesley Gilbertson, and Sanjay Datta. In Vitro Fertilization: A Comparison of $1.5 \%$ and 5\% Spinal Lidocaine for Ultrasonically Guided Oocyte Retrieval. Anesth Analg 1993; 77: 453-56.

2. Martin R, Tsen L, Tzeng G. Anesthesia for in vitro fertilization: The addition of fentanyl 1.5\% lidocaine. Anesth Analg. 1999; 88: 523-6.

3. Tsen L, Schultz R, Martin R. Intrathecal low dose bupivacaine versus lidocaine for in vitro fertilization procedures. Reg Anesth Pain Med. 2000; 26: 52-6.

4. Botta G, D'Angelo A, Giovanni D. Epidural anesthesia in an in vitro fertilization and embryo transfer program. J Assist Reprod Genet. 1995;12:187-90.

5. M. Zitta, A. Mata, G. Santiago, M.H. Gómez, C.A. Sánchez Sarmiento,C. Avendaño. Deleterious impact of propofol on in vitro fertilization. a prospective randomized trial. Fertility and Sterility, 2013:100:11.

6. Rolly, g. And Versichelen, 1. Comparison of propofol and thiopentone for induction of anaesthesia in premedicated patients. Anaesthesia, 1985; 40: 945-948.

7. Ercan Gurses, Hulya Sungurtekin, Erkan Tomatir, and Hakan Dogan. Assessing Propofol Induction of Anesthesia Dose Using Bispectral Index Analysis Anesth Analg 2004; 98: 128 -31.

8. Salem A El-Shawarby, Raul A Margara, Geoffrey H Trew and Stuart A Lavery A review of complications following transvaginal oocyte retrieval for in-vitro fertilization 2004; 7: 127-133.

9. Christiaens F, Janssenswillen C,Verborgh C, Moerman I,Devroey P, Van Steirteghem A, Camu F. Propofol concentrations in follicular fluid during general anaesthesia for transvaginal oocyte retrieval.Hum Reprod 1999; 14(2): 345-8.

10. Ben-Shlomo I, Moskovich R, Golan J, Eyali V, Tabak A, Shalev E. The effect of propofol anaesthesia on oocyte fertilization and early embryo quality. Hum Reprod 2000; 15(10): 2197-9.

11. Thomas J Ebert, Michael Muzi, Richard Berens, David Gott, John P, Kampine: Sympathetic responses to Induction of anesthesia in Humans with Propofol or Etomidate. Anesthesiology 1992; 76: 725-735.

12. Nitin k. Shah, Matthew Harris, Kavitha govindugari, Hamsa b. Rangaswamy, Heejung jeon:Effect of propofol titration v/s bolus during induction of anesthesia on hemodynamics and bispectral index. Middle East J Anesthesiol. 2011 Jun; 21(2): 275-81.

13. Sennur Uzun, Burcu Akbay Ozkaya, Omer Savasyilbas, Banu ayhan. Effects of different propofol injection speeds on blood pressure, dose, and time of induction: Turk j med sci 2011; 41(3); 397-401

14. Anderson RE, Barr G, Owall A, Jakobsson J. Entropy during propofol hypnosis, including an episode of wakefulness. Anaesthesia 2004; 59(1):52-6.

Copyright: (c) the author(s), publisher. Academia Anesthesiologica International is an Official Publication of "Society for Health Care \& Research Development". It is an open-access article distributed under the terms of the Creative Commons Attribution Non-Commercial License, which permits unrestricted non-commercial use, distribution, and reproduction in any medium, provided the original work is properly cited.

How to cite this article: Yuvaraj MK, Aiyappa DS. The Effect of Three Different Bolus Doses of Propofol Using Total Intravenous Anaesthesia (TIVA) in Patients Undergoing Transvaginal Oocyte Retrieval with Regard to Total Propofol Consumption. Acad. Anesthesiol. Int. 2019;4(1):5-9.

DOI: dx.doi.org/10.21276/aan.2019.4.1.2

Source of Support: Nil, Conflict of Interest: None declared. 